\title{
Community Policing and Vigilantism in Kisii: Towards Non-violent and Inclusive Non-State Policing
}

Wycliffe Nyachoti Otiso

\section{(2) OpenEdition Journals}

Electronic version

URL: https://journals.openedition.org/eastafrica/298

DOI: $10.4000 /$ eastafrica.298

ISSN: 2790-1076

Publisher

IFRA - Institut Français de Recherche en Afrique

\section{Printed version}

Date of publication: 1 May 2015

Number of pages: 99-111

ISSN: 2071-7245

\section{Electronic reference}

Wycliffe Nyachoti Otiso, "Community Policing and Vigilantism in Kisii: Towards Non-violent and Inclusive Non-State Policing", Les Cahiers d'Afrique de l'Est / The East African Review [Online], 50 | 2015, Online since 07 May 2019, connection on 10 October 2022. URL: http://journals.openedition.org/ eastafrica/298 ; DOI: https://doi.org/10.4000/eastafrica.298 


\title{
Community Policing and Vigilantism in Kisii: Towards Non- violent and Inclusive Non-State Policing
}

\author{
Wycliffe Nyachoti Otiso ${ }^{1}$
}

\begin{abstract}
The paper studies the changing nature of local policing and argues that there has been a shift from vigilantism, where the vigilante has been the dominant non-state actor, to community policing in Taraacha location situated in Kisii County. The changes are characterized by a move towards non-violent forms of policing. Notwithstanding a number of changes, the transition is not seamless as the discourses on inclusion are nuanced by asymmetries in administration and community cooperation, inadequate support for community policing and existing cultural constructs on governance. The state's continued reliance ${ }^{+}$on the constitutive force of law as the main intervention in the regulation of public order has had minimal success thus far. Rather, local democratization processes appear to have had better success in regulating and facilitating non-state policing activities. The case of Kisii County exemplifies the place of local conceptions and applications of democratic ideals including wider representation, accountability, equitable relations with the police and positive impact on the policing environment generally, hence contributing to the emergence of an inclusive and non-violent community policing structure.
\end{abstract}

African nations have had chequered experiences with regard to the efficacy of non-state policing. It has been no different in Kenya where non-state policing has brought a sharp focus into the relations between the state and society in the regulation of order and in the implementation of law. Over the years, the maintenance of order by non-state groups in Kisii County has been associated with violence and crime. In 2010, a new constitutional order was adopted laying a framework for new governance structures and the consolidation of democracy. Later that year, the Prohibition of Organized Crime Act (POCA) was enacted, banning the activities of armed groups implicated in crime and violence. Establishment of new governance structures and attempts at consolidation of democracy and enforcement have resulted in different trajectories in the mode of non-state policing. The study analyzes trends in policing public order by non-state groups in Kisii County and the interaction with changes brought about by law reform and democratization processes.

The study was conducted in Nyaribari Chache sub-county in Kisii County. It involved several phases of data collection in the different sites of study: January-March 2013; February-May 2014; and August-September 2015. Informal interviews were mainly used in collecting data from former vigilante members and community police. Information was

\footnotetext{
${ }^{1}$ Wycliffe Nyachoti OTISO is a Lecturer at Kisii University and a PhD Fellow at Universite de Pau et des Pays de L’Adour. Email nyachoti@yahoo.com
} 
mainly sourced from Taraacha, Irondi and Nyabiosi sub-locations in Taraacha district. Information was also collected from former vigilante members and district leaders in other parts of the County like Kisii Central, Bobaracho and Bomorenda wards and Nyanchwa and Nyamage locations. In all the areas studied semi-structured interviews were also used to collect citizens' perceptions on the impact of community policing on security.

\section{Understanding Non-State Policing}

Much of the early academic attention on studying non-state policing focused on analysing society self-help groups as competing against the state for the monopoly of the use of force, other scholars viewing groups like vigilantes as inflicting violence against the state. With the realization of non-state policing as a "labile" phenomenon, the focus has changed. (Abrahams, 2010: 1,2) The study of non-state policing has moved away from prescribing a central theory of non-state policing to the causality of global factors shaping vigilantism in different jurisdictions to studying the dynamism of vigilantes catalyzed by attendant local level social structures. Further, academic attention is now starting to change focus to examine vigilantism and community policing as "two sides of the same coin". They should not be viewed through rigid binaries as: legal/illegal; violent/non-violent; illegitimate/legitimate; rather there should be recognition that although they are different types of non-state policing, they may have similar features and challenges. For instance, generalizations that vigilante groups are violent and community policing is non-violent, and vice versa, may not necessarily be valid in the light of emerging practices.

The study reviews new forms of non-state policing in Kisii suggesting that there are both differences and similarities in approaches to policing between vigilante groups and community policing groups. Data reveals nuances in the study of non-state policing groups which calls for a rethinking of the place of non-violence in non-state policing, moving away from preoccupation with the study of violence in vigilante and community policing groups. Indeed, it is important to extend scholarship to non-violent state policing by examining nonviolence, not only how society has brought about non-violence but also how non-violence has changed the community. (Ahluwalia et al, 2006: 2, 3) Similarly, it is useful to understand the use of violence in some circumstances and not in others, and hence why selective violence occurs. (Kalyvas, 2006)

Baker conceptualizes policing as "any organized activity whether by the State or nonstate groups that seeks to ensure the maintenance of communal order, security through the elements of prevention, deterrence, investigation of breaches and punishment" (Baker, 2008:1) The activities of non-state groups that are primarily involved in regulating order meet

\footnotetext{
${ }^{2}$ This term is used in describing the blurred line between community policing and vigilante groups. See Fourchard, 2011: 607
} 
the characteristics of policing in Baker's definition. In many instances these groups operate with the objective of protecting societal order and the preservation of security and this objective is pursued by investigation of breaches of communal norms, dispute resolution and enforcement of punishment. As a result non-state groups' enforcement of communal order serves as a deterrent to the rest of the community ${ }^{3}$. The activities of private security firms could be interpreted as falling within the description of policing as investigation and punishment for the preservation of communal order. However, in the context applied in the paper, the concept of policing is limited to initiatives by the community to preserve public order and does not extend to protection of private commercial interests, which forms the core business of private security firms.

\section{Non-state Policing in Kisii}

Since 1991, a number of non-state groups have existed in Kisii, but they were scarcely involved in the aspects of policing understood as investigation and punishment of breaches in order to maintain communal order. For instance, the chinkororo group was established to protect the territorial security of the community, while others like the amachuma claimed to protect communal order yet their activities were largely associated with the protection of the personal interests of political 'big men' (Masese \& Mwenzwa, 2012: 6487). Neither group applied investigative mechanisms in their operations nor did they punish offenders for breaches of community norms. Instead threats and actual violence were meted out against political opponents in the case of amachuma, while chinkororo arose to protect the community's territorial borders in response to cattle rustling from neighbouring communities and inter-community border clashes. Chinkororo was formed as a defence group where state security machinery was slow to respond to cross-border insecurity and police were in many instances complicit in aggression. (Republic of Kenya, 1999) However, in the past two decades, non-state policing for the maintenance of communal order was dominated by sungusungu for about 15 years, while in the last four years the community policing initiative has begun to take root culminating in the introduction of the Nyumba Kumi initiative in 2013.

The study reveals that there is a changing pattern in non-state policing where to a certain extent participatory processes are practised resulting in inclusive forms of punishing crime. There appears to be a reclaiming of stakes in security as evidenced by increased state interest in community-led initiatives. (Otiso \& Kaguta, 2015) It is not conclusive that embracing ideals of participation and accountability amounts to a complete transition to democratic policing. As currently practised, they are indicative of the different directions that non-state policing groups are taking. Non-state policing groups like the Community Policing

\footnotetext{
${ }^{3}$ However, this objective is not always implemented because there have been many instances where non-state police contribute to breaches of societal order. See Otiso, 2014: 179
} 
Group (CPG) have endeavoured to act within legal structures by working in partnership with local administration and police. Independent of state resources and facilitation, they have organised themselves into representative groupings that practise inclusive participation through non-violent means. However, the gain in legal consciousness and application of democratic practices by informal policing groups is more a product of local application of legal and democratic opportunities.

\section{Vigilantism in Kisii}

Although, the exact time of year remains debatable, there is general consensus that sungusungu started among the Sukuma and Nyamwezi living in rural areas of North Western Tanzania. (Bukurura, 1996: 257-258; Mkutu, 2010: 184) The Sukuma and Nyamwezi mobilized communities to protect property and provided a dispute resolution mechanism for disputes among community members. Sungusungu was adopted by the Kuria in Northern Tanzania who were neighbouring communities to the Sukuma and the Nyamwezi. The system then spread to the Kuria in Kenya (Heald, 2007:1-2) and subsequently to Kisii in the 1990s.

The operation of sungusungu from its inception to the banning of the group in 2010 reveals a history of the use of violence in the tackling of crime. The group resorted to disproportionate responses to crime in which suspected murderers were killed. (Otiso, 2014:179) Persons believed to be witches were rounded up and burnt in public while their homesteads were torched. In many instances sungusungu itself was implicated in crime and contributing to the prevailing problem of insecurity. Further, according to the Commission of Inquiry into Post Election Violence, the vigilante group was guilty of the perpetration of postelection violence.(Republic of Kenya, 2008) However, since the promulgation of the constitution in 2010 and proscription of vigilantes later that year through the Prevention of Crime Act (POCA), there appears to be an emergence of a different trajectory to vigilantism and non-state policing in general. Notable changes include a change of name, a resort to direct political participation and ostensible espousal of non-violent order and dispute resolution.

\section{Change of Name}

The name of the group changed from sungusungu to the Community Policing Group (CPG). It is a strategic means of operating within the law, in the light of the new law (POCA). Beyond the practical measure of changing name to overcome the ban, sungusungu used the same law that prohibits it to create an opportunity by clothing itself with the legal status of a state policing institution ("community policing") initiated in 2011 in Kisii by the 
chiefs and the police. "We are community policing" was the response of a former member to describe the new structure of sungusungu. As a result of the ban, there has also been a change of character and operations of the group. The group previously undertook overt operations including policing public order in the transport sector and collection of garbage in cooperation with the former municipal council. It has now changed to partly covert operations with the group now concentrating on surveillance at night and cooption of intelligence units amongst informal sector hawkers. The change from overt to covert operations is by no means an indication of the neutralization of the group. Neither does it amount to the success of the constitutive force of the law. The group continues to exist albeit with less extensive and overt operations but with a more specific focus and organisation. While before sungusungu operated in daytime by assisting local government in law enforcement, after the ban they resorted to night-time surveillance. In Nyanchwa area, any movement is monitored by members of the group. New vehicles that are driven in the neighbourhood are flagged down and inspected before being allowed to proceed ${ }^{4}$.

\section{Direct Participation}

The political strategies of former sungusungu changed from indirect to direct participation. This shift manifested itself in the leaders' direct participation in election politics in $2013^{5}$. The CPG chairman contested the Kisii Central county ward representative elections rather than supporting incumbent political patrons. The shift in participation changed from traditional forms of accessing decision making through patron-client networks which had provided an indirect and often unreliable access to power. The decision to participate was influenced by a number of factors including disconnection from unreliable patronage, economic opportunities and a perceived new political system. This, it is argued is a nuanced form of engagement in political processes by vigilantes in Kisii. It marks a change in the role of vigilante groups influencing local political processes through non-violent forms by using peaceful electoral processes, rather than resorting to the use of violence to influence outcomes of elections by intimidating opponents of their former political patrons. It marks an ostensible, if puzzling, shift that former users of violence in 2007-2008, have turned to preaching peace and security as a platform to participate in political life and access decisionmaking. Put differently, former users of violence in the 2007 elections advocated non-violent participation in the 2013 elections. This scenario, to an extent, is attributable to a number of factors that created the wider peaceful atmosphere within which the elections were conducted $^{6}$. Other local factors included disconnection from unreliable patronage networks

\footnotetext{
${ }^{4}$ Observation in Nyanchwa area in Kisii Central Ward

${ }^{5}$ Otiso, 2014: 179-180, 182

${ }^{6}$ Thibon, 2014: 14-15
} 
and increased local governance and economic opportunities under the new constitutional dispensation.

There appears to be no significant link between the new political role of the CPG leader participating in elections and vigilantism. Heightened political activity of the vigilante group was centred on the electioneering period. In the aftermath of the elections, there has been minimal political activity by the CPG chairman. Firstly, the CPG chairman did not contest the results in 2013 and soon after the election, he fell sick. It was also widely expected by CPG members that after recovering from illness the chairman would chart alternative political leadership in opposition to the incumbent but none has been forthcoming. At the moment it is uncertain whether the CPG will run again for the elections in 2 years time, but one cannot completely rule out such a possibility. ${ }^{7}$

\section{Institutionalization of community policing in Kisii}

It is not clear when exactly the community policing initiative was introduced in different locations in Kisii County save for one location ${ }^{8}$ that kept records of the first training and elections of area community policing officers. In Taraacha location, official community policing 9 (OCP) began taking root a year after the promulgation of the Constitution and the banning of organized crime groups like sungusungu in 2010. Community members were concerned that the problem of levels of crime and insecurity that bedevilled the community prior to the advent of sungusungu persisted in the area after the banning of the group. In 2011, a meeting was convened by the area chief and the Officer Commanding Police Station to launch community policing in the area. Community members were briefed about the importance of partnership with police in curbing crime and sensitized on their role in the maintenance of order, after which elections of officials followed.

During the recruitment exercise, it was made clear that to be eligible for election as an OCP member, one must be a person of integrity and not have a criminal record. These criteria were adhered to by Taraacha citizens to ensure that the new organization entrusted with maintaining security was composed of law-abiding citizens. Anyone suspected to have been a member of the banned sungusungu group (including CPG members) was considered to be of questionable character and therefore could not be elected to serve as a member of OCP.

\footnotetext{
${ }^{7}$ Interview with G,CPG leader, Nyamage, 15 September 2015

${ }^{8}$ Minutes of Inaugural meeting titled "Kisii Central Community Policing, Keumbu Division, Taraacha SubLocation Seminars" dated 31, March, 2011, in file with the author.

${ }^{9}$ The distinction and emphasis is made between 'official' and non-official community policing because sungusungu have in the recent past changed their name to the Community Policing Group
} 


\section{Representation and Participation}

Community policing in Taraacha location embraces ideals of representative membership of the basic administrative unit (sub-location), observing equity in the number of representatives elected. This model of community policing as practised in Taraacha strives to ensure that with wider participation of members of the community, there is increased participation in crime control and decision making on security and governance. Taraacha location consists of 3 sub-locations namely; Taraacha ${ }^{10}$, Irondi, and Nyabiosi. At location level the group consists of 60 members, with 20 members from each of the sub-locations. They have officials who include the chairperson, vice-chairperson and secretary. The chief acts as the overall leader of this group but the day-to-day activities of the group are carried out by the chairs from the sub-locations with assistance from the secretary and vicechairperson. OCP is formally open to members of the community above 18 years with no upper age limit ${ }^{11}$. In practice, for a person to become a member of this group, one must be 30 years and above but not above 60 years $^{12}$. The OCP membership is balanced between the youth $^{13}$ and older members of society ${ }^{14}$. Apart from chiefs and sub-chiefs, who retire at the age of 65 years, the mandatory retirement age set by the state, there is a significant number of members of the group that are above the age of 35. In particular the executive positions in the OCP are occupied by older citizens. The chairperson, secretary and vice-chairperson are all above 35 years of age. The rationale for the decision to elect older officials is that the community deems the youth not to be "ready" for leadership positions preferring the older members as more capable and experienced to be entrusted with leadership. While cultural constructs still prevail in delimiting the place of youth in governance, interestingly there is a deliberate creation of opportunities for increased participation by women in Taraacha OCP.

\section{The Place of Women and Youth in Community Policing}

Unlike other non-state groups that have existed in Kisii like sungusungu and amachuma, the OCP in Taraacha is not a preserve of male youth. There is a conscious effort to ensure that at least 1 out of 3 members at the village level is a woman. The OCP member stated that this ratio was in line with the constitutional stipulation on gender parity ${ }^{15}$. "We

\footnotetext{
${ }^{10}$ This is one of the sub-locations which shares the same name as the (Taraacha) location where the Chief's headquarters is situated

${ }^{11}$ Other attributes include: no criminal record, person of high integrity and honesty; must be influential, "warm character" and a role model

${ }^{12}$ Interview with C, OCP member, Taraacha sub-location, June 10, 2014

${ }^{13}$ Adopting the constitutional concept of youth as persons between the age of 18 and 35 years. Article 260 of the Constitution defines youth to mean the collectivity of all individuals who have attained the age of 18 years but have not attained the age of 35 years.

${ }^{14}$ Interview with K, Irondi sub-location, May 292014

${ }^{15}$ Article 27 (8) of the Constitution states that the State shall take legislative and non-legislative measures to ensure that not more than two-thirds of the members of elective or appointive bodies shall be of the same gender
} 
Les Cahiers d'Afrique de l'Est

have gender!" the member responded to our question as to the relative increased involvement of women, unlike other non-state policing groups. Out of the 60 members, there are 15 women, with one village having two representatives out of the three members. Boruma Getare provides an interesting scenario as it comprises 2 women and 1 man. However, despite the exceptional case of Boruma Getare and despite concerted efforts, it must be noted that female members are still very few compared to men.

A community policing official noted that female members are few since they cannot participate in the many activities of the group which at most times require the use of force, for instance, in arresting suspects. In his view, women are not involved in patrols because these are largely conducted at night, which is quite dangerous. Further, the social and cultural norms of the community prohibit the involvement of women. As the respondent stated, “...it is against cultural convention for women to protect the community while the husbands are in the house sleeping". He also stated subsequently that it would also avoid any allegations of adultery or affairs with fellow community policing members. However, even though their participation in community policing is limited to daytime operations, female members play a vital role in community policing. These female members act as intelligence officers which the respondent notes is a significant component in the investigative function of the group. Alongside other, male members, the intelligence officers' unit provides information crucial to preventing incidents of crime and insecurity. The membership of the group may be expanded depending on the state of security: where there is an increase of crime rates, more members may be recruited.

OCP is formally open to members of the community over 18 years with no upper age limit $^{16}$. However, the age of members ranges from 28 to 70 years. The rationale behind the age set is that by the age of 28 one is assumed to have married, and therefore be ready for the demands of governance. OCP membership is balanced between the youth ${ }^{17}$ and older members of society ${ }^{18}$. Apart from the chief and sub-chiefs, who retire at the age of 65 years, the mandatory retirement age set by the State, there is a significant number of members of the group that are above the age of 35 . However, the executive positions in the OCP are largely occupied by older citizens. The chairman, secretary and treasurer in Taraacha sub-location are all above 35 years.

Cultural dictates continue to exist in favour of elders especially in leadership positions. The decision to elect older officials is based on the community's view that the youth are not "ready" for leadership positions. Conversely, the elderly are thought to be more capable and

\footnotetext{
${ }^{16}$ Other attributes include: no criminal record, a person of high integrity and honesty who must be influential, a "warm character" and a role model

${ }^{17}$ Adopting the constitutional concept of youth as persons between the age of 18 and 35 years. Article 260 of the Constitution defines youth to mean the collectivity of all individuals who have attained the age of 18 years but have not attained the age of 35 years.

${ }^{18}$ Interview with K, Irondi sub-location, May 292014
} 

experienced, hence they are entrusted with leadership. Though there is no written rule on how the officials should be chosen it seems to be an accepted tradition that seniority, in terms of age, takes precedence. For example, the current locational chairman at Taraacha is 60 years old.

As Akama (2006) explains, political organisation amongst the Abagusii was based on the "lineage system, ebisaku, starting from the smallest socio-political unit, the homestead, enyomba or omochie, to the sub-clan or clan level". The Gusii lineage system followed patrilineal principles that entailed tracing one's descent on the male side. The basic social organization was the homestead headed by a family patriarch, omogaka bwo omochie ${ }^{19}$. (Akama \& Maxon 2006: 82) Based on the lineage system, Gusii culture vested leadership in elders and did not envisage youth leadership. At the clan level, elders of the homestead would exercise political decisions on behalf of the clan. Dispute resolution, sanctions and decision making on important issues including protection of the community from external aggression would be made by the elders. These cultural norms have been applied over the years to the exclusion of youth from active participation in governance of the community.

On the other hand, the youth are expected by the community to be independent, to marry and to provide for their family. Requirements for independence have been modified and are now pegged on completion of one's studies. The youth are expected to achieve all this, yet they have no means of livelihood with the reality of high unemployment rates and limited accessibility to family resources like land. It is only in the neighbouring Irondi sublocation where the average age of officials is about 35 years and below. Irondi sub-location is actually led by the chairman who is 34 years old. The election of the youthful chairmen at the branches of the organisation signals a gradual but slow ceding of space for youth leadership by community members. Cultural constructs still prevail in delimiting the place of male and female youth in governance.

\section{Accountability and Non-violence}

OCP is answerable to the assistant chief. The group draws its members from all corners of the sub-location. Officials of the group are delegated with the responsibility of executing the orders made by the chief. They hold regular and emergency meetings whenever called upon in dispensing their duties. Much as they are accountable to the administration, it appears that they are not subservient to state structure as they enjoy a strong working relationship with the assistant chief. Frequently they act autonomously, where circumstances $\operatorname{dictate}^{20}$. However, unlike vigilantes, they are cognizant that they do not have the mandate to punish

\footnotetext{
${ }^{19}$ It means the (old) man of the household or the head of the household

${ }^{20}$ Interview with A, Location OCP official, June 3, 2014, Kisii; Interview with B, OCP member, 4 July 2014 , Kisii
} 
suspects. Understanding the role of the local administration and police, the OCP have little opportunity to resort to violent means of punishing crime. In response to questions about the guiding principles, a group official responded that they highly regard discipline, justice and the law amongst themselves and in their operations" ${ }^{21}$. As one OCP official stated "the law does not allow..." them to mete out any punishment against the suspect. There is recognition that the local Birongo police post has the jurisdiction to handle all the criminal matters arising within Taraacha location and the role of community policing entails providing intelligence, investigation and arrest.

The relations between the community, assistant chief and the police is suggestive of a budding working relationship between state officials and community policing officials, unlike previous community policing initiatives, and early cooperation between the former provincial administration and vigilantes, which was fraught with conflict and competition. The chief and the police are cognizant that they owe reciprocal accountability to members of the community and even as they direct the crime control process, unpopular decisions not in consonance with aspirations of members of the community will erode the budding partnership and goodwill. There is constant sharing of information between the police at Birongo and the OCP in Taracha effected through phone calls and courtesy visits. The relationship between the two is well-coordinated: the police assist the group by detaining extreme criminals, while the group assists them by providing intelligence, investigation, arresting suspects and handing them over to the police ${ }^{22}$. There is also inter-locational cooperation as the group maintains a very strong partnership network with other OCP groups in the larger Keumbu Division in ensuring safety.

While these relations appear to be cordial, asymmetries still exist ${ }^{23}$. The location OCP leader complained that the police are not transparent in their partnership with the community policing. He noted that after OCP officials handed over arrested suspects to them, there was minimal transparency as to the procedure for further investigation and terms of release. The OCP members feel that while they work hard to provide intelligence and arrest suspects, the police are compromised through acceptance of bribes. Hence over time it has eroded the partnership between the community and the police, as the latter remain as the dominant organ that primarily directs and controls the process of crime control. Further, the release of suspects in unclear circumstances is frustrating to OCP members because they have no mechanism for holding the police accountable.

\section{Challenges}

\footnotetext{
${ }^{21}$ Interview with E, OCP official June 3, 2014, Boruma I

${ }^{22}$ Interview with police officer, Birongo police post, 4 July 2014

${ }^{23}$ Interview with A, Location OCP official on September, 23, 2015 (repeat interview) revealed instances of disharmony between police and OCP leader
} 
"We know that the guiding principle is that Community policing is a voluntary exercise and requires personal sacrifice but we do not receive any financial support from the government", a community policing member laments when asked what are the major challenges to community policing ${ }^{24}$. The main financial support that the group receives is drawn from contributions made by members of the community. For instance, members of the community make contributions during public barazas to enable the group to purchase torch batteries for use in their night patrols. They do not draw a salary or wages from the government, nor do they gain any from the police or the chief.

Due to lack of financial support, the group has developed its own financial streams for self-sustenance and upkeep akin to the fundraising mechanisms of vigilante groups. OCP members stated that victims of theft, creditors, give a token as a form of appreciation for the good job done by the group in investigation and arresting of the suspect. For example, a person whose money has been recovered through the help of OCP usually offers a token to the community policing members involved in the debt recovery or recovery of stolen goods. However, one member was quick to qualify that these tokens are not what sustains members but rather their desire to tackle crime. He stated that the group draws its motivation from the moral support and good will from community members as the community appreciates the work they do. They also rely on the support of "good Samaritans" in society, mostly well-todo civilians who give them rewards of their own volition. Such "good Samaritans" are community members including former policemen, retired court clerks, civil servants and other professionals, who not only donate some funds to OCP but also provide advice on legal requirements that relate to arrest and enforcement.

In contrast with CPG, the OCP is an apolitical organization. It does not actively participate in any political activities or elections as a group; hence its members do not get any favours or funding from politicians. The group faces several other challenges. Firstly, they lack appropriate clothing useful in the execution of tough roles associated with their activities, such as boots and warm clothing as they undertake night patrols. Further, they lack equipment necessary for carrying out their job. Lastly, most of newly recruited OCP members lack the experience that older members possess. The long-serving members have learnt policing skills on the job over time. The fresh recruits lack adequate training, save for an inaugural seminar which provided tips on how to arrest and handle suspects. This may reduce their capacity to deal with tactical issues like reduction of crime by preventive means without resorting to punishment.

\section{Conclusion}

${ }^{24}$ Interview with I, OCP member, Irondi, May, 29, 2014 
The study makes a number of broad observations; there exist plural policing mechanisms in Kisii comprising state and non-state policing; increased domination over policing using the law as currently designed has had limited success in tackling crime; and local level mobilization of legal and institutional reforms has created new opportunities in governance. Local conceptions and informal civil awareness that such reforms facilitate new democratic opportunities for increased citizen participation and empowerment have been more successful in the production of inclusive and non-violent regulation of order. Consolidation of democratic policing and governance will face challenges in the absence of active citizen involvement, acceptance and reflection of people's aspirations at the local level. Entrenchment of inclusive community policing and avoidance of relapses into violence will also much depend on the furtherance of collaborative citizen and state engagement. To harness already existing local conceptions on new democratic governance, formal civic awareness programmes are needed to sensitize communities on opportunities for new democratic governance and advocacy for non-violent dispute resolution.

\section{Bibliography}

Abrahams, Ray. “Foreword.” In Domesticating Vigilantism in Africa, ed. Thomas Kirsch and Tito Gratz. Suffolk: James Currey, 2010

Ahluwalia, Pal, Louise Bethlehem \& Ruth Ginio. "Introduction." In Violence and NonViolence, ed. P. Ahluwalia, L. Bethlehem and R. Ginio, 1-11. New York: Routledge, 2006.

Akama, John \& Robert Maxon. Ethnography of the Gusii of Western Kenya: A vanishing Cultural Heritage. New York: Edwin Mellen Press, 2006.

Baker, Bruce. Multi-choice Policing in Africa. Uppsala: Nordiska Afrikainstutet, 2008

Bukurura, Sam. "Combating Crime among the Sukuma and Nyamwezi of West Central Tanzania." Crime, Law and Social Change 24 (1996): 257-266.

Fourchard, Laurent. "Politics of Mobilization for Security in South African Townships." African Affairs, 110/441, (2011): 607-627

Heald, Suzette. "Making Law in Rural East Africa: Sungusungu in Kenya" Crisis States Programme Working Paper 12, Series 1 (2007)

http:/www/crisisstates.com/Publications/wp12.htm

Kalvyas, Stathis. The Logic of Violence in Civil War. Cambridge: Cambridge University Press, 2006.

Masese, Eric \& Ezekiel Mwenzwa "The Genesis and Evolution of Sungusungu Vigilante groups among the Abagusii Ethnic Group of Kenya." Elixir Social Science, 42 (2012): 64856492. 
Mkutu, Kennedy. "Mitigation of Armed Criminality through an Indigenous Approach: The Case of Sungusungu." Law and Social Change 53(2010): 183-204.

Otiso, Wycliffe. (2014) "Evaluation of Political Mobilization Strategies Employed by Vigilante Groups in Kisii County during the 2013 Kenyan Elections." In Kenya's Past as Prologue: Voters, Violence and the 2013 General Elections, ed. Christian Thibon, MarieAude Fouere, Mildred Ndeda, and Susan Mwangi. Nairobi: Twaweza/ Heinrich Boll, 2014.

Otiso Wycliffe \& Joyce Kaguta. Kenya at Fifty: State Policing Reforms, Politics and Law, 1963-2013. Ohio: Palgrave Macmillan, 2015.

Republic of Kenya. Report of the Judicial Commission of Inquiry into Tribal Clashes in Kenya. Nairobi: Government Printers, 1999.

Republic of Kenya. Prevention of Organized Crime Act. Nairobi: Government Printers, 2010.

Republic of Kenya. The Constitution of Kenya, 2010. Nairobi: Government Printers, 2010.

Ruteere, Mutuma \& Marie-Emmanuelle Pommerolle. "Democratising Security or Decentralising Repression: The Ambiguities of Community Policing in Kenya." African Affairs 102 (2003): 587-604.

Thibon, Christian. "Kenyan Elections: When does history repeat itself and does not repeat itself?" In Kenya's Past as Prologue: Voters, Violence and the 2013 General Elections, ed. C. Thibon, M.A. Fouere, M. Ndeda, and S. Mwangi. Twaweza/ Heinrich Boll, 2014. 